\title{
EMIGRATION FROM VOJVODINA PROVINCE
}

DOI: http://dx.doi.org/10.18509/GBP.2015.33

UDC: 314.15-026.49(497.1444),,1960/2011“6

\section{Ass. Prof. Dr. Milka Bubalo-Živković \\ Ass. Prof. Dr. Tamara Lukić \\ Dr Bojan Đerčan}

Faculty of Science, Department of Geography, tourism and hotel management, University of

Novi Sad

\begin{abstract}
Emigration from the whole territory of Serbia and from Vojvodina, the northern province, has been present since 1960s. Nevertheless, due to the bad economic-political situation during the 1990s, the number of emigrants from Vojvodina increased. In the first decade of the 21 st century, the number of emigrants was somewhat smaller but still larger than the number of emigrants during the 1960s, 1970s and 1980s. Countries which were attractive to emigrants during the economic migrations of 1960s, such as Germany, Austria, Switzerland, the USA, were also the countries in which the biggest number of emigrants from 1991 to 2011 settled. Hungary, as the nearest country, is also interesting to a large number of emigrants. Novi Sad, the biggest and most populated center of Vojodina, has the biggest number of emigrants. Subotica, Sombor, Vršac, Zrenjanin are also the leading centres of emigration.
\end{abstract}

Keywords: emigration, Vojvodina, Serbia

\section{INTRODUCTION}

Vojvodina, the northern province of Serbia, takes $24,3 \%$ of the territory of Serbia with Kosovo and Metohija. According to the 2011 census, Vojvodina had 1,931,809 inhabitants, $27,1 \%$ of the total number of people in the Republic without Kosovo and Metohija. This is the most populated region of Serbia after the region of Belgrade $(89,8$ inhabitants per $\mathrm{km}^{2}$ ). The biggest concentration of people is in the region of Novi Sad, which has intensive migration processes. The municipality of Novi Sad and municipalities which belong to the Novi Sad gravity zone (Temerin, Petrovaradin) are the only ones with the recorded increase in number of inhabitants between the two censuses. Number of inhabitants is also large in the municipalities of Subotica, Zrenjanin and Pančevo. Nevertheless, decrease in number of inhabitants has been recorded in these municipalities. In municipalities of Subotica and Zrenjanin the number of inhabitants has decreased since 1981 census, while in Pančevo the number has been decreased only in the last period between the two censuses. Besides Novi Sad, which represents an immigration area, rest of the Vojvodina territory is the area of emigration, leaving for big centres or abroad. For Novi Sad and its gravity zone are typical both immigration from smaller centres and villages and emigration to other countries. Increase in number of inhabitants in the area of Novi Sad between the two last censuses is exclusively concequence of immigration. Birthrate is significantly low. In the period from 1991-2001, 697 was the number of newborns $(2,5 \%)$, while in the last period it was $924(2,9 \%)$. Influence of low birthrate on growth of population of Novi Sad could be seen in the fact that in the period between 1991 and 2002 the number of inhabitants increased for 33830 persons, while in the period between 2002 and 2011 it increased for 42331 persons. It can 
be concluded that immigration is the main cause of increase in number of inhabitants in Novi Sad. In other municipalities in Vojvodina, negative birthrate is evident, especially in the period between 2002 and 2010. Nevertheless, decrease in number of inhabitants is bigger than the negative values of birthrate, which indicates the presence of emigration process from municipalities of Vojvodina.

\section{SOURCES OF INFORMATION AND METHODS OF WORK}

Information from the 2002 and 2011 censuses on emigrants from the Statistical Office of the Republic of Serbia have been used in this work. However, it does not represent the exact number of persons who left Serbia. These records are in connection with emigrants who have members of family who had stayed in Serbia, who provided the Institute with the information on emigrants [6]. However, number of whole families who moved out together is big and nobody gives information about them. Based on this and on different numbers being mentioned, we can see how difficult it is to obtain reliable estimation. Serbian diaspora claims that the exact number of emigrants from Serbia in the world is „practically impossible to estimate“.

Analyses in this work have been done based on the records from the Statistical Office of the Republic of Serbia because the same method had been used for processing the data on emigrants to all countries. We had used the records of individual destination countries, we would have problems due to different approaches to the records. Analysis has been done for the periods from 1991 to 2001 and from 2002 to 2011 according to the 2002 and 2011 censuses. Obtaining and processing data on emigrants on both censuses were generally the same. Nevertheless, during the 2002 census there were attempts to obtain information on emigrants by the lists from abroad which were shared on the borders around the New Year (just before the census) ${ }^{11}$.

Analysis of distribution of emigrants by years of emigration, emigration directions, part of emigrants from Vojvodina to individual countries from the total number of emigrants from the Republic of Serbia to these countries and distribution of emigrants in municipalities of Vojvodina have been done.

\section{EMIGRATION FROM VOJVODINA}

In the period after the WWII, more intensive emigration from ex-Yugoslavia started in the 1960s (more precisely in 1966 with the conveyance of bilateral international employment contracts), when the largest number of emigrants left for central European and western European countries. Large number of emigrants from this period had completed lower education. Emigration of highly educated persons begins with the 1970s. This has been intensified in the last two decades [4].

Emigration from Serbia is a significant factor of depopulation. It influences educational structure, as well, which is especially evident during intensified emigration of highly educated people. Migrations of scientists and professionals from developing into developed countries in the 20th and the beginning of the 21 st century are big. According to Grečić [3], 40000 of them (about 7,6\% of total number of emigrants from Serbia) emigrated to northern America and EU countries during the last decade of the 20th and the first decade of the 21 st century. What Serbia loses and what the countries which attract highly-educated people gain shows the fact that the product of one professional, according to the estimation of international organizations (from the mid 1990s of the last century)

\footnotetext{
${ }^{11}$ However, response had been so insignificant that the idea was dejected on the last census.
} 
costs about 300000 dollars. Based on this fact and on the number of emigrated „brains“, Grečić [2] estimates that Serbia has lost about 12 billion dollars through the emigration of scientists and engineers in the last two decades. Apart from the emigration of highly educated professionals, loss is great due to emigration of other educated people, as well. Region of Vojvodina significantly takes part in total process of emigration from the Republic of Serbia, which is shown in the following analyses. Table 1 contains records from the 2002 and 2011 censuses. According to the 2002 census records, numbers of emigrants recorded on that census are given, as well as of those who had emigrated in some earlier period. During the 1960s, 4,085 persons emigrated from Vojvodina. In the following decade this number is almost tripled. According to the 2002 census, 11,848 persons had emigrated in that period. In this period emigrations were intensive due to the work abroad. Number of emigrants keeps being big in the 1980s, as well - 11,567.

Table 1. Number of emigrants from Vojvodina by intercensal periods according to 2002 and 2011 censuses records

\begin{tabular}{|c|r|r|r|r|r|c|}
\hline & \multicolumn{7}{|c|}{ Emigration periods according to 2002 census } & $\begin{array}{c}\text { Records } \\
\text { from } \\
2011 \\
\text { census }\end{array}$ \\
\hline $\begin{array}{c}\text { Emigration } \\
\text { periods }\end{array}$ & $\begin{array}{c}1960 \text { and } \\
\text { earlier }\end{array}$ & $1961-1970$ & $1971-1980$ & $1981-1990$ & $1991-2001$ & $2002-2011$ \\
\hline $\begin{array}{c}\text { Number of } \\
\text { emigrants }\end{array}$ & 67 & 4,085 & 11,848 & 11,567 & 34,469 & 30,994 \\
\hline
\end{tabular}

Source: Statistical Office of the Republic of Serbia, Results of additional data processing of 2002 and 2011 censuses, Belgrade.

Nevertheless, the intensity of emigration was specially strong during the 1990 s, due to a bad political and economic situation in the country. However, during the data collection for the 2002 census, number of those who could give information on emigrants from the new period was much bigger than of those who could provide us with the information on emigrants from the 1960s. Reason for this is death or emigration of the whole family which has taken place during the years. According to the results of 2011 census, 30,994 persons emigrated in the period from 2002 to 2011, what is somewhat less than in the preceding period (1991-2001), when 34,469 persons had emigrated (table 1).

In the period from 1991 to 2001, based on 2002 census, 34,469 persons emigrated from Vojvodina. In the same period 212,972 persons emigrated from whole Serbia, without Kosovo and Metohija, so that emigrants from Vojvodina took part with only $16,2 \%$ of total number. Largest number of emigrants left Vojvodina in 1992 (5,716 persons) as a concequence of the beginning of war in ex Yugoslavia. People mostly emigrated due to difficult economic and political situation. At the end of the 20th century (1999 and 2,000), according to the census of 2002, number of emigrants increased in comparison with the preceding years. A large number of emigrants from Vojvodina for the period from 1991 to 2001 is recorded for $2000,10.0 \%$ of total number (table 2).

Table 2. Emigrants from Vojvodina by years of emigration

\begin{tabular}{|c|c|c|c|}
\hline \multicolumn{2}{|c|}{2002 census } & \multicolumn{2}{|c|}{2011 census } \\
\hline Year & Number & Year & Number \\
\hline 1991 & 2,424 & 2002 & 763 \\
\hline 1992 & 5,716 & 2003 & 1,119 \\
\hline 1993 & 2,386 & 2004 & 1,296 \\
\hline 1994 & 2,474 & 2005 & 1,453 \\
\hline
\end{tabular}




\begin{tabular}{|r|r|r|r|}
\hline 1995 & 2,256 & 2006 & 2,254 \\
\hline 1996 & 2,244 & 2007 & 1,866 \\
\hline 1997 & 2,655 & 2008 & 2,305 \\
\hline 1998 & 2,079 & 2009 & 2,985 \\
\hline 1999 & 3,274 & 2010 & 2,787 \\
\hline 2000 & 3,448 & 2011 & 14,166 \\
\hline 2001 & 1,839 & \multicolumn{2}{|}{}
\end{tabular}

Source: Statistical Office of the Republic of Serbia, Results of additional data processing of 2002 and 2011 censuses, Belgrade.

According to the results of 2011 census, with the beginning of the first decade of the 21 st century, number of emigrants from Vojvodina decreased. Political changes in Serbia took place in 2000. From that period, people had hoped for economic improvements in the state, however, intensity of emigration from 2007 shows that people lost their faith in improvement [4]. In 2007, 2008 and 2009, 26\% of emigrants from the period of 20022010 left. Only in 2011, 45,7\% of total number of emigrants from the period mentioned left (table 2). There are immigrants who have been less than a year abroad. According to 2011 census results, $13,9 \%$ of total number of emigrants from Serbia were from Vojvodina.

Residents and citizens from the region of Vojvodina live in big numbers in countries all around the world. Some reduction in number of emigrants is evident from the period of 1991-2001 to the period of 2002-2010. Reduction in scope of emigration is evident to the countries most attractive to emigrants from Vojvodina (Germany, Austria, Hungary, Switzerland, the US, Italy). According to the 2002 census, 7,730 persons emigrated from Vojvodina to Germany in the period of 1991-2001, whereas 4,682 persons emigrated in the period of 2002-2011. In the same period, reduction of emigration is evident to other countries, as well. Number of emigrants to Austria is reduced from 5,320 to 3,750 persons, to Hungary from 4,451 to 3,287 persons, to Italy from 1,951 to 1,914 persons, to the US from 2,095 to 1,852 and to Switzerland from 2,129 to 1,688 persons. Based on the results of 2002 census, 1,866 persons emigrated to Canada in the period of 1991-2001, and 917 to Australia. Based on the results of 2011 census, 810 persons emigrated to Canada in the period of 2002-2011, and 386 to Australia (graph 1). Emigration to Hungary is not typical only for the population of Hungarian nationality. It is typical for the people of Serbian nationality, as well. Countries like Slovakia, Czech Republic, Slovenia, Croatia were attractive to emigrants, as well, in the first decade of the $21 \mathrm{st}$ century. Largest number of these emigrants consists of people who are of these nationalities, which means that they were leaving for their fatherlands, especially after the same countries became members of the European Union, and due to the difficult economic situation in Serbia. According to the 2011 census, over 1,200 persons emigrated to Montenegro. This emigration has been intensified since Montenegro separated from Serbia in 2006. Certain number of people who emigrated to Arab countries (United Arab Emirates dominate with more than 200 persons) is evident. Over 1,200 emigrants from Vojvodina lived in Bosnia and Herzegovina at the time of 2011 census. 


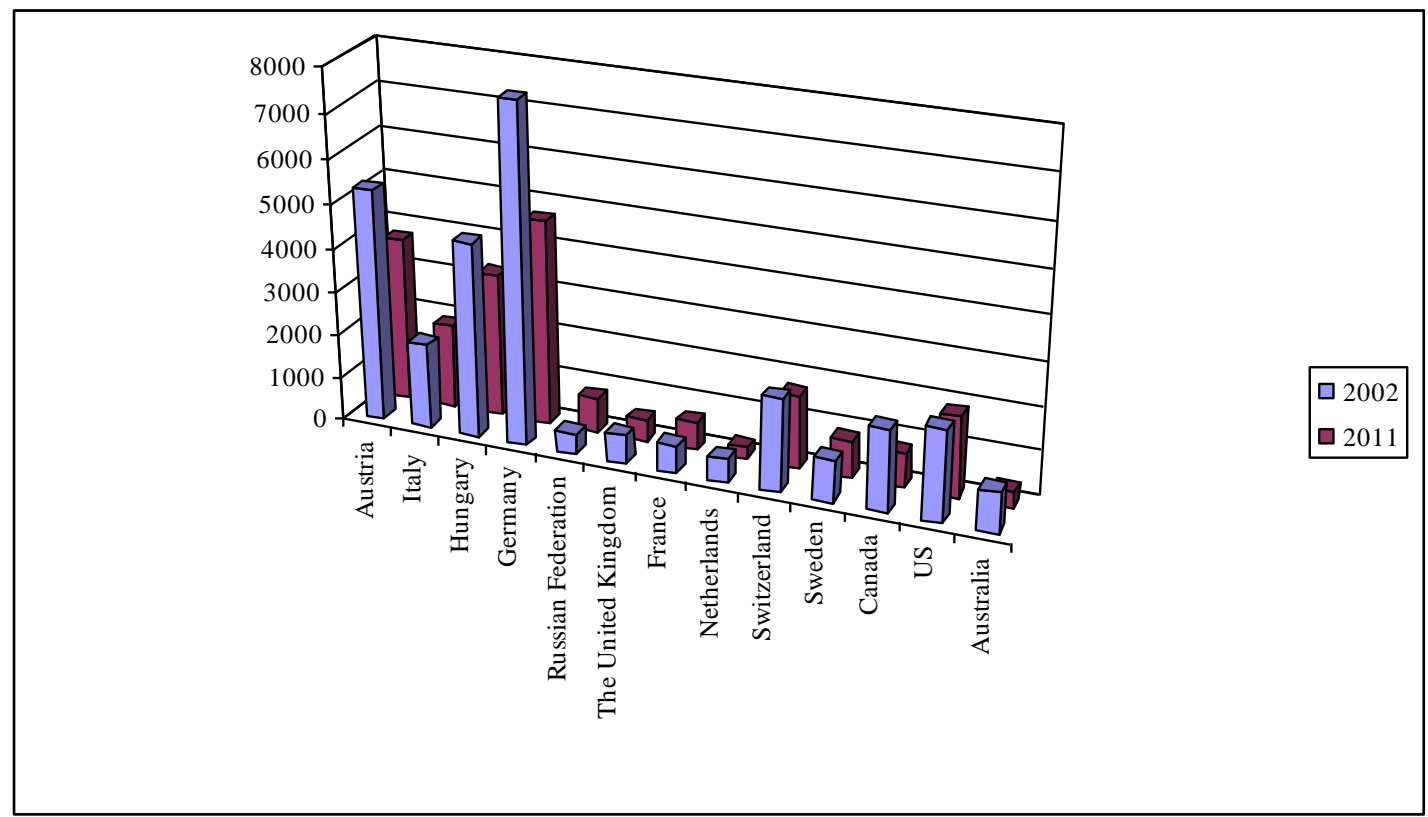

Graph 1. Countries towards which emigration was most intensive according to 2002 and 2011 censuses Source: Statistical Office of the Republic of Serbia, Results of additional data processing of 2002 and 2011 censuses, Belgrade.

Region of Vojvodina is specific for large numbers of emigrants who move to particular destinations. The largest number of immigrants to Hungary originates from Vojvodina. These emigrants take the biggest part in the number of emigrants from Serbia moving to Hungary, more than $93 \%$ in 2002 and more than $94 \%$ in 2011. More than one fifth of emigrants to Australia and Great Britain are from Vojvodina (according to both censuses). Around one fifth of emigrants from Serbia to the US are from Vojvodina. Number of emigrants from Vojvodina in comparison with the total number of emigrants from Serbia is significantly increased towards the countries such as Germany and Russia. The smallest number of emigrants from Vojvodina is towards destinations like France and Switzerland (table 3).

Table 3. Number of emigrants from Vojvodina from total number of emigrants from Serbia by emigration countries

\begin{tabular}{|l|r|r|}
\hline Emigration countries & \multicolumn{1}{|c|}{2002} & \multicolumn{1}{|c|}{2011} \\
\hline Austria & 14.0 & 10.2 \\
\hline Germany & 16.3 & 19.4 \\
\hline Switzerland & 6.8 & 8.1 \\
\hline Italy & 11.9 & 12.0 \\
\hline France & 6.8 & 6.2 \\
\hline US & 19.1 & 21.2 \\
\hline Sweden & 14.6 & 15.1 \\
\hline Canada & 22.5 & 23.0 \\
\hline Russian Federation & 10.7 & 15.7 \\
\hline Hungary & 93.5 & 94.8 \\
\hline Netherlands & 16.7 & 13.5 \\
\hline Australia & 23.5 & 20.3 \\
\hline Great Britain & 21.3 & 20.7 \\
\hline
\end{tabular}

Municipalities in Vojvodina with the biggest number of citizens also have the biggest number of emigrants (Novi Sad, Subotica, Pančevo, Zrenjanin, Sombor, Sremska 
Mitrovica, Vršac). According to the 2002 census, 4,510 persons emigrated from the municipality of Novi Sad, and according to the 2011 census, 3,791 persons (or 4,328 together with municipality Petrovaradin, which is 2011 singled out as a separate municipality), 1,476 persons emigrated from the municipality of Sombor (2002), and 1,235 persons in 2011. Number of emigrants decreased in majority of municipalities in the two observed periods. In 17 municipalities the number of emigrants increased in these two censuses, in Apatin, Kula, Odžaci, Opovo, Bač, Bačka Palanka, Bačka Topola, Subotica, Bački Petrovac, Beočin, Sremski Karlovci, Sremska Mitrovica, Titel, Vrbas, Novi Kneževac, Šid, Novi Bečej. Emigration from smaller muncipalities was intensified in 2011 due to bigger economic problems, more difficult employment, deterioration of most industrial facilities in them. The number of emigrants leaving from north Bačka and Banat municipalities (Apatin, Subotica, Bačka Topola, Novi Kneževac) has increased due to extensive emigrations to Hungary.

Banat municipalities, that have a border position (Alibunar, Bela Crkva, Vršac, Žitište, Plandište, Sečanj), had a higher share of emmigrants in the total population of the municipality, among them a greater share emmigrants in the total population was with municipalities Kovačica and Kovin. In Bačka was the largest share of emmigrants in the total population in the municipalities of Ada, Apatin, Bac, Bački Petrovac, Kanjiža, Senta. Unfavorable geographic location (border character) is one of the important factors that affect emigration from the municipalities along with the economic and political situation. With space Srem largest share of immigrants in the total population was from the municipality of Sremska Mitrovica, Ruma, Indjija, Sid and Zemun. These municipalities have the largest population in the region.

Emigration intensity from Vojvodina province municipalities is dependent on their geographic location and economic situation [4] [1]. Political and economic situation in Serbia has strong impact on emigration. Municipalities with all industrial facilities being shut down (as municipality of Kula) have got an additional push factor resulting in emigration of citizens to bigger cities or abroad.

\section{CONCLUSION}

Vojvodina takes almost one fourth of total area of Republic of Serbia and more than one fourth of total number of citizens live here. Nevertheless, number of emigrants from Vojvodina from the total number of emigrants from Serbia between the two periods (1991-2001 and 2002-2010) was decreasing. Number of emigrants was bigger between 1991 and 2002 censuses. Oscilation in numbers which follows economic-political situation in Serbia is evident inside intercensal periods, as well. Emigration was mostly directed towards the countries to which emigration from whole Serbia was directed Germany, Austria, Italy, US, Switzerland. The only country towards which the emigrants from Vojvodina, but not from whole Serbia, were directed is Hungary. Economic development and the closeness to Vojvodina influenced on intensified emigration to Hungary.

Largest number of emigrants is from municipalities with the largest number of citizens. However, emigration from these municipalities is decreased from 1990s in comparison with the first decade of 21 st century. At the same time, municipalities with smaller number of citizens have small increase in number of emigrants in these two periods, which is in connection with economic situation in the country and the region of Vojvodina itself and the economic situation in the municipalities. 
What could keep citizens stay in Vojvodina? What could bring back numerous people who have already found jobs abroad?

Improvement of economic situation and of political issues are the only solutions. Opportunities for employment according to the level of education and adequate payment for work which could enable normal life conditions would definitely keep people in Vojvodina and attract those who have already emigrated.

\section{ACKNOWLEDGEMENTS}

This work is a part of the project „Population and settlements of Vojvodina“, financed by Matica srpska.

The authors would like to express their sincere thanks to the Provincial Secretariat for Science and Technological Development of the Vojvodina Province, Republic of Serbia - Project No. 114-451-3602/2014-01, for the financial support.

\section{REFERENCES}

[1] Bubalo Živković, M., A. Ivkov, T. Kovačević (2007). Migracije u Bačkoj od II svetskog rata do 2002. godine, Demografija, 4: 103-116.

[2] Grečić, V. (1996). Migracije visokostručnih kadrova i naučnika iz SR Jugoslavije. Savezno ministarstvo za razvoj, nauku i životnu sredinu; Institut „, Mihajlo Pupin“, Centar za istraživanje razvoj nauke i tehnologije: Institut za međunarodnu politiku i privredu, Beograd.

[3] Grečić, V. (2010). Srpska naučna dijaspora: „tamo i ovde“. Beograd: Institut za međunarodnu politiku i privredu.

[4] Bubalo Živković, M.; B. Djerčan; T. Lukić; G. Jovanović (2014). „Moving to the Welfare Countries: Emigrants from Serbia 1961-2002“. European Researcher, LXXI, , 3-2: 581-594.

[5] Statistical Office of the Republic of Serbia, Results of additional data processing of 2002 and 2011 censuses, Belgrade.

[6] http://www.srpskadijaspora.info/vest.asp?id=16927 (observed 3. 8.2014. godine). 
